\title{
Challenges on the Implementation of Free Education Policy in Tanzania: A Case of Public Primary Schools in Babati Town
}

\author{
Fabian Doriye, Dr. Mussa S. Muneja*, Dr. Onesto llomo \\ University of Arusha, Tanzania \\ *Corresponding Author: momuneja@gmail.com
}

\begin{abstract}
The aim of the study was to analyze the challenges facing implementation of free education policy in Tanzania among selected Public Primary Schools in Babati Town. The study used descriptive research design by applying quantitative research approach. Teachers were selected using total population sampling. Since the study involved only 13 schools, it was easy to collect data from all 147 teachers. The data collection instruments were validated by expert judgement from University of Arusha Research Board. Moreover, a pilot study was done and the tool was revised accordingly. The data was coded in SPSS software and descriptive analysis was used to collect data. The first objective was about teaching based challenges faced by teachers under the current policy of free education at public primary schools. The overall finding shows the teaching based challenges have exponentially increased as seen in the shortage of classrooms, availability of large number of students in small classrooms and making it harder for teachers to facilitate crowded classrooms. The second objective was geared to describe management-based challenges faced by heads of schools under the current policy of free education. The overall findings show that head teachers worked in harder environments as compared to when the free education policy was not in operation. It is recommended that the government of Tanzania should increase education funding in order to make free education policy relevant. Also it is further recommended that the government should give clear explanation of what free education is all about in order to make parents be willing to support schools through material and moral support.
\end{abstract}

Key words: Challenges, Free education, head teachers, Babati, Tanzania

\section{Introduction}

Free education is a historical global agenda. In 1948, the United Nations (UN) established the Universal Declaration of Human Rights which supports promotion of several human rights including free education. Article 26 of the Universal Declaration of Human Rights advocates for free access to primary and secondary education (UN, 1948). In 1960, the Convention against Discrimination in Education was formulated under the United Nations Educational Scientific and Cultural Organization (UNESCO). Article 4 of the convention emphasizes member states under UNESCO to take measures to make free and compulsory primary education whilst ensuring equal access to secondary education (UNESCO, 1960).

Moreover, in 2005 the United Nations Children's Fund (UNICEF) and the World Bank launched the School Fee Abolition Initiative (SFAI) which was designed to support developing countries in maintaining and sustaining provision of universal primary education (UNICEF \& World Bank, 2009). In 2015, United Nations formulated 17 Sustainable Development Goals (SGDs) seeking to end poverty in the world by 2030. SDG 4 intends to ensure inclusive and equitable quality education and promote lifelong learning opportunities for all. In order to achieve the goal, it is envisaged that by the year 2030, boys and girls should have access to free and quality primary and secondary education for effective learning outcomes (UN, 2019). Apart from the UN, regional and international organizations have also made initiatives to promote free education. For instance, in 1979 the African Union (AU), formerly known as the Organization of African Union (OAU) formulated the African Charter on the Rights and Welfare of the Child. Article 11 promotes the right to education by emphasizing governments to provide free primary and secondary education (AU, 1979). 
Several countries in the world have taken legal steps to permit free education. According to a report by UNESCO, until 2018, a total of 161 countries in the world had already taken legal measures to allow free primary and secondary education (UNESCO, 2018). Developed western countries such as Canada, United States of America, New Zealand, France and Australia have been offering free primary education for the past 100 years. Asian countries have witnessed a slow pace in providing free primary education. All Latin American countries provide free primary education except Colombia. Sub-Sarahan Africa countries offer free education except Somalia, Sudan, Angola, Gabon, the Ivory Coast and Cameroon. Yet parents are required to incur costs for purchasing school supplies (Lowe, 2019). For instance, Ghana introduced free primary and junior high school education in 1995 and introduced free high school education in 2001 (Forson, 2017). Kenya introduced free primary education in 2003 (Muyanga, Olwanda, Mueni, \& Wambugu, 2010) and Tanzania re-introduced free primary and secondary education in 2015 (HakiElimu, 2016).

Studies have shown challenges in implementing free education policy. A study by Cheruto and Benjamin, (2010) found that effective implementation of free education in primary schools in Keiyo District in Kenya is hindered by management challenges such as shortage of staff, limited financial management skills, resistence from parents and inadquate physical facilities. Another study done by Edho (2009) found that provision of free universal basic education in Delta State in Nigeria is facing challenges such as poor funding, poor motivation of teachers, improper supervision and inadquate teaching and learning facilities.

Similarly, in Tanzania the policy of free education has triggered unprecedented increase of enrollment in government primary schools. Between 2014 and 2016 enrollment rate in Standard I among government primary schools increased by $41.4 \%$ (PORALG, 2016). Moreover, education outcomes in public primary schools remain low with $28 \%$ of standard seven leavers lacking ability to read, write and count (UNICEF, 2018). Based on the foregoing backdrop, this study explored challenges facing implementation of free education policy at school level in Babati District. This study was guided by three objectives, namely;

1. To describe teaching based challenges faced by teachers under the current policy of free education at public primary schools in Babati Town.

2. To describe management-based challenges faced by heads of schools under the current policy of free education at public primary schools in Babati Town.

\section{Literature Review}

This part presents a review of literature and theories governing the study.

\section{Policy Review}

Tanzania is among the countries that implement free education policy. The History of free education in the country dates back in 1974 when the Universal Primary Education (UPE) policy was introduced. UPE resulted to rapid increase in enrollment rate from $56 \%$ in 1974 to $98 \%, 110 \%$, $111 \%$ and $168 \%$ in 1975, 1976, 1977 and 1978 respectively (UNICEF \& World Bank, 2009). During this period, all social services in Tanzania including education were financed by the government. However, in 1980 s the country was hit by serious economic crisis that undermined capacity of the government to provided free education. In response to the crisis, the government requested assistance from the World Bank with a strict condition of restructuring socio-economic policies. The government embarked on cost-cutting and costsharing policies which ended the free education (Oketch \& Rolleston, 2007).

Subsequently, in 2002, Tanzania introduced cost sharing policy in secondary education. Fees at secondary school level were charged from 20,000 to 40,000 Tanzanian Shillings per year. However, parents were required to make contributions for school maintenance. In 2015, the policy of costsharing in secondary education was reversed with circulars reflected from the Education and Training Policy of 2014 which emphasized on provision of free education. For instance, the Education Circular No. 5 of 2015 which was issued in November that year, required all public education management bodies to ensure that primary and secondary education were provided free of charge. Following the circular, the government disbursed 18bn Tanzanian Shillings to schools to cover the cost of implementing the new directive, with $137 \mathrm{bn}$ setaside to cover the full cost of guaranteeing free education for all for the period of January 2015 to June 2016 (HakiElimu, 2016). 


\section{Theoretical Literature Review}

This study was guided by three theories namely resource based theory, organizational effectiveness theory and cost sharing theory.

\section{Resource Based theory}

The resource-based view is brought to view by Burney, Wright \& Ketchen Jr., (2001). The theory places emphasis on examining the link between "firm's internal characteristics and performance." The theory assumes that resources constitute the important source of competitive advantage of a firm. Firm's resources are assets and capabilities possessed by an organization. They constitute human resources, physical resources, information, knowledge and financial resources. These resources enable an organization to envisage and execute strategies that can lead to improvement of performance in terms of "efficiency and effectiveness."

The theory was applied to formulate the variable on resource management based challenges such as limited finance to operate schools, limited capacity to expand school infrastructure, inability to run school feeding programs, inability to motivate teachers through financial incentives and limited capacity to purchase teaching and learning resources.

The theory, however, is criticized for focusing on internal factors while overlooking external factors that may affect utilization of resources. Organizations are influenced by external surroundings such as political, legal, economic, social and technological forces which may affect performance (Scott, 2003).

\section{Organizational Effectiveness Theory}

Organizational effectiveness is the extent towards which an organization is able to utilize its resources efficiently and meet its stated goals. Organizational effectiveness is measured by indicators like inputs, outputs and outcomes. Inputs criteria measure performance by focusing on knowledge, skills, structures and efforts of employees. Inputs indicators further focus on capacity of an organization to attain its stated goals. Output is a result which can be measured quantifiably. For example, monthly profit and monthly sales. An organization can measure outputs by counting sales and profits. This theory is applied to investigate opinion of teachers about inputs, outputs and outcome challenges faced in teaching primary school pupils under the policy of free education. The assumptions of this theory were used to construct one of the variables of the study that is teaching based challenges. Input based challenges are related to teaching materials and facilities such as books and classrooms. Output based challenges are related to quantity of pupils who pass standard seven examinations. Outcome based challenges are related to quality of pupils that are produced under the current policy of free education.

\section{Empirical Literature Review}

This section presents the related literature in terms of empirical findings from various countries.

\section{Teacher and Management Based Challenges}

Various studies have shown teaching based challenges faced by teachers under policies of free education. A study by Kindyamtima, (2017) sought to determine the perceptions of heads of schools and teachers on a free education reform in secondary schools, identifying the challenges facing heads of schools in managing public secondary schools and identifying the strategies used by the heads of schools in subsidizing grants given by the government in managing the schools in Dodoma region, Tanzania. The study adopted mixed research approach which employed descriptive survey design so as to accomplish the objectives of the study. Eighty respondents were selected among the secondary school teachers of Dodoma municipality and Kondoa District. The study found that free education has led to increase in enrollment in public secondary schools. Consequently, the increase in enrollment rate accelerated the challenge of scarcity of teaching resources and facilities such as books, classrooms and libraries. While findings of the study were limited to public secondary schools in Dodoma, this study sought to cover the gap by describing perceptions of teachers on teaching based challenges faced under implementation of the policy of free education in Babati Town.

Another study done in Tanzania is that by Khamis (2017) who examined challenges facing Head Teachers in implementing Free Primary Education (FPE) policy in public primary school in Unguja, Zanzibar. In attempt to achieve the objective, the study gathered opinion of teachers. The results revealed that teachers faced a number of challenges in implementing free education. Such challenges included parents' misconceptions about free education policy, delays in provision of teaching 
materials, poor teaching and learning environment and deteriorated school infrastructure.

\section{Provision of Training and Awareness on Free Education Policy}

Studies have recommended that challenges facing implementation of free education policy can be addressed through provision of training and awareness to stakeholders including heads of schools, teachers and parents. A study by Kindyamtima, (2017) done in Dodoma, Tanzania, recommended that the responsible Ministry should consider training of stakeholders since the free educational reform had left out the heads of schools and teachers. In essence, when the government advocates free education, it means waiving school fees. But all other supportive fees and other related expenses such as charges for uniforms, school means, and learning materials, among others, are not included. In similar vein the study done by Khamis (2017) in Unguja, Tanzania, recommended that there is a need to provide training and awareness to heads of schools about management of finances under the policy of free education. This is because school heads are in charge of managing large amount of finances with little knowledge of financial management. Moreover, the study recommended that there is a need to provide awareness to parents about free education policy in order to avoid confusion and lack of support from parents.

\section{Involvement of Parents}

Studies have also recommended that effective implementation of free education policy will be effective if there will involvement of parents. A study by Khamis (2017) recommended that free education policy in Zanzibar can be effectively implemeted through active involvement of parents. This strategy will help to address the challenge of misconceptions among parents about free education policy which resulted to poor participation of parents in contributing towards what is called free education. Parents can be involved through school committees which are composed by representatives of parents. Moreover a study by Serem and Ronoh (2012) in the context of implementation of free education policy in Pastoral communities in Kenya, recommended that pareents should be involved in fund raising activities necessary for funding education. One of the ways through which parents can contribute is by selling cattles to finance education projects.

\section{Methodology of the Study}

This part presents the methodology that guided the study. It highlights on the research design, population and sampling, data analysis procedures, validity and reliability and ethical considerations.

\section{Research Design}

The study used descriptive research design which is used in describing characteristics of a research phenomenon (Happener, Kivlighan, \& Wamplod, 2008). Descriptive studies may combine both qualitative and quantitative data to answer research questions. Descriptive studies can employ surveys and interviews to collect data (Sim \& Wright, 2000). The descriptive design facilitated the study to describe challenges facing implementation of free education policy in Tanzania by focusing on public primary schools in Babati Town.

\section{Population and Sampling}

Babati Town has 29 government primary schools. Hence, the study selected 1 school from each ward to ensure representation of all eight wards, namely Babati, Bagara, Bonga, Maisaka, Matuka, Nangara, Sigino and Singe. Hence a sample of 8 schools was involved in the study. The study employed stratified sampling where by each ward formed a stratum. So in each ward, a simple random sampling was done to select one school and out of one school all teachers were selected to participate in the study. A total number of 147 teachers filled the questionnaires.

\section{Data Analysis Procedures}

The study employed standardized questionnaire to collect data. The data were analyzed by means of measurement of central tendency to describe the average of opinion of respondents. Data were collected using a closed ended questionnaire by which respondents were asked to select answers from a list of alternative responses.

\section{Validity and Reliability}

Validity is the accuracy of research instrument by ensuring the test measures what it intended to measure. One of criteria of validity is content validity. Content validity measures the extent to which content of research instruments accord with concepts informing the study. In order to ensure content validity, the questionnaire was reviewed by two education experts from the University of Arusha to ensure the content relates to concepts and theories governed by the study. Secondly the prior to the actual data collection, the questionnaire was 
disturbed to a group of 40 teachers in a school which was not included in the sample and the test yielded the Cronbach alpha of 0.7 and above, meaning the instrument was reliable for data collection.

\section{Ethical Considerations}

Ethical considerations were met in the fact that respondents were allowed to freely participate and were not required to indicate their names on the questionnaire for confidentiality reasons. Furthermore, the researchers sought for permission from government authorities in Arusha Babati District before data was collected from the field.

\section{Results and Discussion}

This part presents the data analysis and discussion of the findings. The findings are based on the two objectives which are; to describe challenges teaching based challenges faced by teachers under the current policy of free education at public primary schools in Babati Town and to describe management based challenges faced by heads of schools under the current policy of free education at public primary schools in Babati Town. The data analysis and presentation were enhanced by the literature review. The analysis was done using descriptive analysis in terms of mean scores. The interpretation scale was as follows:

$\begin{array}{ll}\text { Score range } & \text { Interpretation } \\ 1.00-1.79 & \text { strongly disagree } \\ 1.80-2.59 & \text { disagree } \\ 2.60-3.39 & \text { neutral } \\ 3.40-4.19 & \text { agree } \\ 4.20-5.00 & \text { strongly agree }\end{array}$

Table 1: Teacher Based Challenges

\begin{tabular}{llccc}
\hline SN & \multicolumn{1}{c}{ Challenges that face teachers in public schools } & Mean & Interpretation \\
\hline 1 & Free education policy has increased the challenges of large class size & 4.41 & Strongly agree \\
2 & Free education has increased the challenges of shortage of classes & 4.25 & Strongly agree \\
3 & Free education policy has hindered capacity to manage large classes & 4.29 & Strongly agree \\
4 & Free education policy has hindered capacity to facilitate effective class & 4.13 & Agree \\
& participation among students & & \\
5 & Free education has caused delays in provision of teaching resources & 3.52 & Agree \\
6 & Free education policy has increased the challenges of shortage of books & 2.50 & Disagree \\
7 & Free education has increased the challenge of shortage of libraries & 2.72 & Neutral \\
8 & Free education has resulted to shortage of teachers & 2.71 & Neutral \\
9 & Free education has hindered provision of adequate feedback to students & 4.04 & Agree \\
10 & Fee education policy has resulted to resistance from parents & 4.34 & Strongly agree \\
\hline
\end{tabular}

As presented in the table 1 , item one to three and item ten had mean scores ranging between 4.20 and 5.0. This denotes strongly agree, implying that these pre-conceptualized challenges were strongly agreed as those faced by teachers a result of freed education in public primary schools. With regards to item four, five and nine, the mean score ranged between 3.40 and 4.19 which denotes agree while in item six, the mean ranged between 1.80 and 2.59 implying disagree. Item seven and eight had the mean scores ranging between 2.60 and 3.39 implying neutral.

The items that were generally agreed as challenges are; Free education policy has increased the challenges of large class size, Free education has increased the challenges of shortage of classrooms, Free education policy has hindered capacity to manage large classes, Free education policy has hindered capacity to manage large classes, Free education policy has hindered capacity to facilitate effective class participation among students, free education has caused delays in provision of teaching resources, free education has hindered provision of adequate feedback to students and free education policy has resulted to resistance from parents to contribute for education.

With regards to whether free education has increased the challenge of shortage of libraries and whether free education has resulted to shortage of teachers, the respondents were neutral.

In reference to Table 2, the respondents tended to agree or strongly agree that there are management based challenges faced by heads of schools in relation to the implementation of free education policy. Item three, five and nine had the mean scores ranging between 4.20 and 5.00 denoting strongly agree. In item one, four, six, seven, eight and ten, the mean scores ranged between 3.4 and 4.19. This implies that these variables were generally agreed as the challenges faced by the 
management of schools as a result of free education in public primary schools. The challenges that were agreed as challenges included whether free education policy has increased the challenge of financial resources. The findings match with, the study done by Kindyamtima, (2017) who investigated management challenges faced in implementing free education policy in Dodoma region, Tanzania.

s Table 2: Management Based Challenges

\begin{tabular}{|c|c|c|c|}
\hline & Challenges that face management in free education policy & Mean & Interpretation \\
\hline 1 & Free education policy has increased the challenge of finance resources & 3.90 & Agree \\
\hline 2 & Free education policy has increased delays in receiving of funds & 2.40 & Disagree \\
\hline 3 & Free education has increased challenge of inadequate classrooms & 4.40 & Strongly agree \\
\hline 4 & Free education has hindered the provision of school meals to students & 3.90 & Agree \\
\hline 5 & Free education policy has resulted in low motivation among teachers & 1.70 & Strongly disagree \\
\hline 6 & Free education has resulted to poor teaching and learning environment & 3.40 & agree \\
\hline 7 & Free education has caused a decline in school meal programs & 3.80 & Agree \\
\hline 8 & Free education has caused a decline in the quality of education & 3.40 & agree \\
\hline 9 & Free education has made parents resist contributing to education & 4.20 & Strongly agree \\
\hline 10 & Free education has resulted to shortage of teachers & 3.60 & Agree \\
\hline
\end{tabular}

The findings in this study are in alignment with the study by Serem and Ronoh (2012) on investigating the challenges faced in implementing Free Primary Education policy among pastoralists in Kenya which found that implementing free primary education is hindered by ten challenges constituting of inadequate funding, limited community support, negative attitude towards education, unavailability of social amenities, poor infrastructure that hinder access, limited physical facilities, difficulty in curriculum implementation, school calendar being unsuitable, negative attitude towards teachers and limited awareness towards education.

\section{Conclusions and Reccommendations}

This part climaxes the study by giving conclusions based on the two research objectives and their corresponding reccommendations.

\section{Conclusions of the Study}

The study concludes that the teaching based challenges existed as seen in the shortage of classrooms and large number of learners in small classrooms which made it harder for teachers to facilitate crowded classrooms.

Head teachers faced delays in receiving teaching and learning resources. Finally, free education policy resulted into the resistance from parents to contribute for education.

\section{Reccommendations}

It is reccommended that the government should increase funding to education sector in exponential rates. This will lead to construction of new classrooms, libraries and other school infrastructures. Further, the government of Tanzania should revise the free education policy to cost-sharing education policy. It is also reccommended that the government should give clear directives for parents to support various curriculum and extra-curriculum activities that need funds.

\section{References}

African Union. (1979). African Charter on the Rights and Welfare of the Child. Organization of African Union.

Burney, J., Wright, M. \& Ketchen Jr., D. J. (2001). The resource-based view of the firm: Ten years after 1991. Journal of Management 27(2001), 625-641.

Cheruto, K. L., \& Benjamin, K. W. (2010). Management challenges facing implementation of free primary education in Kenya: A case of Keiyo District . Journal of Education Administration and Policy Studies 2(5) , 71-76.

Edho, O. G. (2009). The Challenges Affecting the Implementation of the Universal Basic Education (UBE) in Delta State, Nigeria. Journal of Social Sciences, 20(3) , 183-189.

Forson, F. K. (2017, September 15). Retrieved September 28, 2019, from

https://www.voanews.com: https://www.voanews.com/africa/ghanalaunches-free- high-school-education.

HakiElimu. (2016). The Impact of the Implementation of Fee-Free Education Policy 
on Basic Education in Tanzania: A Qualitative Study . Dar es Salaam: HakiElimu.

Happener, P. P., Kivlighan, D. M., \& Wamplod, B. E. (2008). Research Design in Councselling . Belmont, USA: Thompson Higher Education .

Khamis, J. M. (2017). Challenges Facing Head Teachers in Implemeting Free Primary Education Policy: A Case Study of Zanzibar West District Unguja. Dodoma: University of Dodoma .

Kindyamtima, E. M. (2017). Challenges Facing Schools Management On The Implementation Of Free Education Reform In Tanzania: A Case of Dodoma Region. Unpublished Master Dissertation. . Dar es Salaam : The Open University of Tanzania.

Lowe, S. (2019, October 2). Which Countries Offer Free Primary Education? Retrieved October 2, 2019, from classroom.synonym.com.

https://classroom.synonym.com/countriesoffer-primary-education-7998042.html

Muyanga, M., Olwanda, J., Mueni, E., \& Wambugu, S. (2010). Free Primary Education in Kenya: An Impact Evaluation Using Propensity Score Methods. In J. Cockburn, \& J. Kabubo-Mariara, Child Welfare in Developing Countries (pp. 125-155). New York: Springer.

Oketch, M. O., \& Rolleston, C. M. (2007). Policies of Free Primary and Secondary Education in East Africa: A Review of Literature. United Kingdom : CREATE.
PORALG (2016). Pre-Primary, Primary and Secondary. Dodoma : PORALG .

Scott, R. W. (2003). Organizations: Rational, Natural and Open Systems. New Jersey: Printice Education Inc.

Serem, D., \& Ronoh, R. K. (2012). Challenges Faced in Implemeting Free Primary Education for Pastoralists in Kenya . Problems of Education in the 21st Century, 41 (2012) , 100-111.

Sim, J., \& Wright, C. (2000). Research in Health Care: Cencepts: Designs and Methods. UK: Stanley Thomes (Publishers) Ltd.

UN. (2019). Sustainable Development Goal 4 (SDG 4). Retrieved September 15, 2019, from sdg4education.org:

https://sdg4education2030.org/the-goal

UN. (1948, December 10). Universal Declaration of Human Rights. Retrieved September 15, 2019, from un.org: https://www.un.org/en/universaldeclaration-human-rights/

UNESCO. (1960, December 14). unesco,org. Retrieved September 15, 2019, from Convention against Discrimination in Education:

http://www.unesco.org/education/pdf/DISC RI E.PDF

UNESCO. (2018, October 10). What you need to know about the right to education. Retrieved September 15, 2019, from en.unesco.org:

https://en.unesco.org/news/what-youneed-know-about-right-education

UNICEF \& World Bank. (2009). Abolition of School Fees in Africa. Lessons from Ethhiopia, Ghana, Kenya, Malawi and Mozambiquw. New York: World Bank. 